Article

\title{
Is the Prevalence of Leishmania infantum Linked to Breeds in Dogs? Characterization of Seropositive Dogs in Ibiza
}

\author{
Maria Edo ${ }^{1}$, Pablo Jesús Marín-García ${ }^{2, *(D)}$ and Lola Llobat ${ }^{2, *(D)}$ \\ 1 Facultad de Veterinaria, Universidad Cardenal Herrera-CEU, CEU Universities, 46113 Valencia, Spain; \\ maria.edo1@alumnos.uchceu.es \\ 2 Department of Animal Production and Health, Veterinary Public Health and Food Science and \\ Technology (PASAPTA), Facultad de Veterinaria, Universidad Cardenal Herrera-CEU, CEU Universities, \\ 46113 Valencia, Spain \\ * Correspondence: pablo.maringarcia@uchceu.es (P.J.M.-G.); maria.llobatbordes@uchceu.es (L.L.)
}

Citation: Edo, M.; Marín-García, P.J.; Llobat, L. Is the Prevalence of Leishmania infantum Linked to Breeds in Dogs? Characterization of Seropositive Dogs in Ibiza. Animals 2021, 11, 2579. https://doi.org/ $10.3390 /$ ani11092579

Academic Editors:

Annamaria Passantino,

Gaetano Oliva, Laura Rinaldi,

Michela Pugliese and Michael

E. Davis

Received: 10 July 2021

Accepted: 1 September 2021

Published: 2 September 2021

Publisher's Note: MDPI stays neutral with regard to jurisdictional claims in published maps and institutional affiliations.

Copyright: (c) 2021 by the authors. Licensee MDPI, Basel, Switzerland. This article is an open access article distributed under the terms and conditions of the Creative Commons Attribution (CC BY) license (https:/ / creativecommons.org/licenses/by/ $4.0 /)$.
Simple Summary: Leishmaniosis is an important zoonotic protozoan disease. Leishmania infantum is a protozoan species that accounts for the majority of cases in the Mediterranean. In this study, we analyzed the prevalence of infection in different dog breeds from Ibizan Island. Our results showed that the Doberman Pinscher and Boxer breeds present a higher prevalence of infection, and the relationship between antibodies' serum titer and staging of disease was confirmed. Differences between age and sex were not found.

Abstract: Leishmaniosis is an important zoonotic protozoan disease primarily spread to the Mediterranean region by Leishmania infantum, the predominant protozoan species, which accounts for the majority of cases. Development of disease depends on the immune response of the definitive host and, predictably, their genetic background. Recent studies have revealed breed-typical haplotypes that are susceptible to the spread of the protozoan parasite. The objective of this study was to analyze the prevalence of leishmaniosis on a Mediterranean island and determine the relationship between disease prevalence and breed. In addition, information on seropositive animals was recorded to characterize animals affected by the disease. To study the prevalence, a total of 3141 dogs were analyzed. Of these, the 149 infected animals were examined for age, sex, antibody titer, and disease stage. We observed a prevalence of $4.74 \%$, which varied between breeds $(p<0.05)$. The Doberman Pinscher and Boxer breeds had the highest prevalence of leishmaniosis. Significant differences were observed between breeds with common ancestors, emphasizing the important genetic component. Finally, regarding the characterization of seropositive animals, the distribution is similar to other studies. We discovered a relationship $(p<0.05)$ between the number of antibody titers and the clinical disease stage, which was also present in Leishmania infantum, suggesting that the development of the disease depends on the humoral or Th2 immune response with ineffective antibodies.

Keywords: Leishmania infantum; dog; Ibiza; prevalence; infection

\section{Introduction}

Leishmaniosis is a parasitic disease caused by different genera of Leishmania, including Leishmania infantum (L. infantum), the most prevalent causal agent of leishmaniosis in the Mediterranean area stretching as far as the Iberian Peninsula. This zoonotic disease is endemic to 88 countries and is considered the most relevant vector-borne disease in the Mediterranean, affecting between $63 \%$ and $80 \%$ of the domestic dog population [1-5]. Akohundi et al., (2016) identified 53 different species of the Leishmania genera and more than 800 vectors capable of transmitting the infection stadium of the parasite (promastigote) to the host [6]. Although domestic dogs are the definitive hosts, different studies have documented L. infantum in other mammalian species, including horses, cats, pigs, 
wild rodents, hares, wild canids, and humans [7-14]. The host immunity response determines the infection severity of L. infantum, which can be mild, moderate, severe, or very severe [15]. Solano-Gallego et al. (2009) reported that the most common clinical signs of infection by L. infantum are skin lesions, generalized lymphadenomegaly, progressive weight loss, muscular atrophy, exercise intolerance, decreased appetite, lethargy, splenomegaly, polyuria and polydipsia, ocular lesions, epistaxis, onychogryphosis, lameness, vomiting, and diarrhea [15]. In terms of spatial distribution, the seroprevalence of L. infantum varies in different Spanish areas, ranging from 3.7\% to $34.6 \%$ in the north and south of the country, respectively $[16,17]$. There are some studies on the prevalence of $L$. infantum on Mediterranean islands [18,19]. Burnham et al., (2020) studied the relationship between anti-Phlebotomus pernicious saliva antibodies in Ibizan hounds and susceptibility to canine leishmaniosis without analyzing seroprevalence data in different dog breeds from the Mediterranean coast of Spain [20]. The global seroprevalence in domestic dogs of the Spanish Mediterranean islands was estimated at approximately 57.1\% [21]. Although numerous studies (in both visceral and cutaneous forms) explored a possible genetic influence or resistance to disease in murine and human models, similar studies in dogs are scarce [22-28]. However, some studies found resistance and/or susceptibility to disease depending on the dog breed, thereby influencing the pathological process $[29,30]$. Recently, Vasconcelos et al., (2019) published a review on dogs' genetic resistance to infection by Leishmania spp., particularly the Ibizan Hound breed, but did not obtain clear evidence [31]. These data complement Solano-Gallego et al.'s study (2000), which demonstrated that the Ibizan Hound presents a greater immune response than dogs of other breeds [30].

The clinical pathogeny of $L$. infantum infection is a multifactorial process, where the activation of Th1 or Th2 pathways depends on the host-pathogen interaction. The cellular immune response or Th1 pathway eliminates amastigotes within the macrophage more efficiently since stimulation by cytokines, mainly interferon-gamma (IFN- $\gamma$ ) and interleukin-2 (IL-2), cause a de-inhibition of nitric oxide production and deactivate the action of the arginase enzyme. The relationship between nitric oxide and arginase is essential for the progression of L. infantum inside macrophages [32-34]. However, recent studies have linked clinical symptoms to an increase in the expression of transforming necrosis factor-alpha (TNF- $\alpha$ ), IL-1 $\beta$, IL-4, IL-10, and IL-12, suggesting that the balance between different cytokines plays an important role in regulating inflammation and clinical presentations of the disease $[35,36]$. Hosts who activate the humoral immune response or Th2 pathway develop the disease with greater prevalence and severity since the antibodies are ineffective and stimulation by cytokines is based on the production of IL-10. This situation favors the development of the parasite along with the arginase enzyme and synthesis of polyamides [37]. Studies in vitro have demonstrated that blocking the activity of receptor IL-10 may be a new effective treatment [38,39].

Some authors have associated this differential immune response to the genetic backgrounds of these canine breeds. Additionally, different canine breeds present different prevalence rates $[40,41]$. Genes related to the activation of Th1 pathways include IL12RB1, JAK3, CCRL2, CCR2, CCR3, and CXCR6, whereas COMMD5 and SHARPIN are associated with the activation of Th2 pathways [37]. Other genes, such as Slc11c11 or Major Histocompatibility Complex I gene ( $M H C I)$, also affect the susceptibility or resistance to L. infantum infection [31]. Batista et al., (2020) associated genetic markers with antibody response in infected dogs [42]. Furthermore, different dog breeds show differences in gene expression. Sánchez-Roberts et al., (2008) postulated that some breeds, such as the Boxer, are most susceptible to infection [43] due to gene expression. These authors conducted a study with 19 breeds (including the Ibizan Hound and Boxer), where they analyzed the presence of polymorphism in the Slc11a1 gene, which is related to autoimmune diseases in humans [44]. They concluded that two of the 24 polymorphisms found in this gene showed greater susceptibility to infection. Six single nucleotide polymorphisms (SNPs) in three different genes were detected in the Beagle breed, correlating with susceptible infection phenotypes [29]. 
Despite several studies regarding the genetic resistance and susceptibility of canine breeds, few have determined the prevalence of this infection in different breeds. Therefore, we aimed to investigate the effect of breed on L. infantum prevalence and characterize the profile of seropositive animals on a Mediterranean island as well as to identify and characterize the profile of seropositive animals.

\section{Materials and Methods}

\subsection{Ethics Approval}

The experiments involving animals were conducted according to the guidelines of the Declaration of Helsinki and approved by the Animal Experimentation Ethics Committee of the Universidad Cardenal Herrera CEU, with code 2020/VSC/PEA/0216.

\subsection{Data and Collection of Samples}

The study was conducted on Ibiza $\left(38^{\circ} 54^{\prime} 31.79^{\prime \prime} \mathrm{N}, 1^{\circ} 25^{\prime} 58.66^{\prime \prime} \mathrm{E}\right.$; an area of $\left.572 \mathrm{~km}^{2}\right)$, a Mediterranean island located east of Spain. Data and blood samples from 3141 dogs with symptoms of L. infantum infection were collected between September 2020 and May 2021 (Table 1) [2]. Blood samples were obtained in $5 \mathrm{~mL}$ EDTA tubes from all symptomatic animals by cephalic venipuncture for serological analysis. Serological analysis was performed for all animals, including those with a positive serological test. The data recovered included prevalence ( 2 levels), breed ( 25 levels), sex ( 2 levels), age (divided into 3 categories: young $(<4$ years), adult $(4 \leq$ years $<10)$, and older dogs $(\geq 10$ years)), presentation of disease (3 levels: cutaneous, visceral, or both), and clinical stage. Four levels (Table 1) were assigned to each animal in a physical exam evaluating clinical signs according to Solano-Gallego et al. [15].

Table 1. Classification of clinical stages based on clinical signs [15].

\begin{tabular}{cr}
\hline Clinical Stage & Clinical Signs \\
\hline Stage I: mild disease & Mild clinical signs, peripheral lymphadenopathy, or popular dermatitis. \\
Stage II: moderate disease & $\begin{array}{r}\text { Clinical signs of stage I include diffuse or symmetrical cutaneous lesions (exfoliative } \\
\text { dermatitis, ulcerations), anorexia, weight loss, fever, and epistaxis. }\end{array}$ \\
Stage III: severe disease & $\begin{array}{c}\text { Clinical signs of stages I and II, include vasculitis, arthritis, uveitis, and glomerulonephritis. } \\
\text { Clinical signs of stages I, II and III, include pulmonary thromboembolism, or nephrotic } \\
\text { stagndrome, and end-stage renal disease. }\end{array}$ \\
\hline
\end{tabular}

\subsection{Serologic Tests}

Blood samples were collected from the cephalic vein in $5 \mathrm{~mL}$ EDTA tubes. Plasma was obtained and preserved at $-20{ }^{\circ} \mathrm{C}$ before analysis. Serological testing for L. infantum detected specific antibodies using the indirect immunofluorescence antibody test (IFAT), which was conducted by an external laboratory, and the IFAT for anti-Leishmania-specific immunoglobulin G (IgG) antibodies (MegaFLUO LEISH ${ }^{\circledR}$, Megacor Diagnostik GmbH, Hörbranz, Austria). Seroprevalence was calculated as the percentage of dogs testing positive for L. infantum antibodies. Dog serum was considered seropositive with IFAT titer $\geq 1: 80$, following the manufacturer's instructions $[45,46]$. The titer of detected antibodies was classified into 3 levels: low or questionable $(<1: 100)$, medium (between 1:100 and 1:400), and elevated (>1:400).

\subsection{Statistical Analysis}

Seroprevalence status was analyzed using the GENMOD procedure of the statistical program SAS (North Carolina State University, USA). Within positive animals, antibody titers were analyzed using a binary (in the case of sex) or multivariable (in the case of breed, age, presentation of disease, and clinical stage) logistic regression model using each factor as a fixed effect in their respective statistical analysis. The statistical significance was set at $p$-value $<0.05$. 


\section{Results}

Table 2 shows the seroprevalence (\%) observed in different breeds using the cut-off of an L. infantum antibody titer $\geq 1: 100$ to denote seropositivity. The total seroprevalence was $4.74 \%$ (149 to 3141 animals studied) and varied between the canine breeds studied ( $p$-value $<0.05)$. The results showed three groups evaluated for seroprevalence: The first group (Table 2, superscript a) with the lowest prevalence (on average $1.73 \%$ ) comprised the Pug (0.72\%), French Bulldog (1.41\%), Maltese Bichon (1.47\%), Chihuahua (2.33\%), and crossbreeds (2.74\%). The second group (Table 2, superscript b), with medium prevalence, contained only the German Shepherd (7.38\%). The third group (Table 2, superscript c) with the highest prevalence (34.26\% on average) comprised the Pointer $(24.49 \%)$, Dogue de Bordeaux (33.33\%), Great Dane (33.33\%), Majorcan Shepherd (33.33\%), Weimaraner (33.33\%), Boxer (39.13\%), and Doberman Pinscher (42.86\%) breeds. The animals that do not present statistically significant differences are indicated by more than one superscript. Dogs belonging to the Beagle breed (Table 2, with superscripts a and b) only show statistically significant differences compared with the Boxer breed (Table 2, superscript a) and German Shepherd (Table 2, superscript b).

Table 2. Prevalence of Leishmania infantum according to canine breed.

\begin{tabular}{|c|c|c|c|}
\hline Breed & Studied Dogs & Seropositive Dogs & Seroprevalence (\%) \\
\hline Beagle & 16 & 1 & $6.25^{a b}$ \\
\hline Maltese Bichon & 68 & 1 & $1.47^{\mathrm{a}}$ \\
\hline Boxer & 23 & 9 & $39.13^{c}$ \\
\hline Bull Terrier & 16 & 2 & $12.50 \mathrm{bc}$ \\
\hline French Bulldog & 426 & 6 & $1.41^{\mathrm{a}}$ \\
\hline Pug & 138 & 1 & $0.72^{a}$ \\
\hline Chihuahua & 172 & 4 & $2.33^{a}$ \\
\hline Cocker Spaniel & 41 & 11 & $26.83^{c}$ \\
\hline Doberman Pinscher & 7 & 3 & $42.86^{\mathrm{c}}$ \\
\hline Dogue de Bordeaux & 3 & 1 & $33.33^{c}$ \\
\hline Golden Retriever & 23 & 2 & $8.70^{b c}$ \\
\hline Great Dane & 6 & 2 & $33.33^{\mathrm{c}}$ \\
\hline Jack Russell & 34 & 3 & $8.82^{b c}$ \\
\hline Labrador Retriever & 103 & 14 & $13.59 \mathrm{bc}$ \\
\hline Mastiff & 22 & 2 & $9.09 \mathrm{bc}$ \\
\hline German Shepherd & 271 & 20 & $7.38^{b}$ \\
\hline Majorcan Shepherd & 3 & 1 & $33.33^{c}$ \\
\hline Pinscher & 55 & 2 & $3.64^{\mathrm{ab}}$ \\
\hline Pitbull & 18 & 1 & $5.56^{\mathrm{ab}}$ \\
\hline Pointer & 49 & 12 & $24.49^{c}$ \\
\hline Pomeranian & 14 & 2 & $14.29 \mathrm{bc}$ \\
\hline Schnauzer & 8 & 1 & $12.50 \mathrm{bc}$ \\
\hline Spitz & 6 & 1 & $16.67^{b c}$ \\
\hline Weimaraner & 3 & 1 & $33.33^{c}$ \\
\hline Yorkshire & 47 & 3 & $6.38^{a b}$ \\
\hline Crossbreed & 1569 & 43 & $2.74^{\mathrm{a}}$ \\
\hline \multirow[t]{2}{*}{ Overall } & 3141 & 149 & 4.74 \\
\hline & $p$-value & & $<0.05$ \\
\hline
\end{tabular}

$\overline{\mathrm{a}, \mathrm{b}, \mathrm{c}}$ Seroprevalence with no common superscripts differ significantly at $p<0.05$.

Table 3 describes the seropositive animals based on sex, age, presentation of the disease, and clinical status. The number of seropositive males was higher than females. Younger dogs and adults had higher seropositivity than older dogs, with a cutaneous presentation of the disease in clinical stage II (Table 3). 
Table 3. Data recovered of seropositive dogs.

\begin{tabular}{ccc}
\hline Variable Analyzed & Categorical Factors & Distribution of Seropositive (\%) \\
\hline Sex & Male & 60.26 \\
\multirow{2}{*}{ Age } & Female & 39.74 \\
& Young $(<4$ years $)$ & 54.97 \\
& Adult $(4 \leq$ years $<10)$ & 38.41 \\
Presentation of disease & Older $(\geq 10$ years $)$ & 6.62 \\
& Cutaneous & 62.91 \\
& Visceral & 35.10 \\
Clinical stage & Both & 1.99 \\
& I & 15.89 \\
& II & 58.28 \\
& III & 24.50 \\
& IV & 1.32 \\
\hline
\end{tabular}

No observable effects were detected between antibody titers, and canine breed, sex, or age. However, antibody titers were recorded in seropositive animals ranging from 1:100 to 1:1280, which is associated with presentation of disease $(p$-value $<0.05)$ but not canine breed, sex, or age ( $p$-values of $0.97,0.46$, and 0.43 , respectively).

Only one dog with a high level of antibodies $(>1: 400)$ presented as clinical stage I $(p$-value $<0.05)$. Animals with a low antibody titer $(<1: 100)$ had clinical stages III or IV (Figure 1).

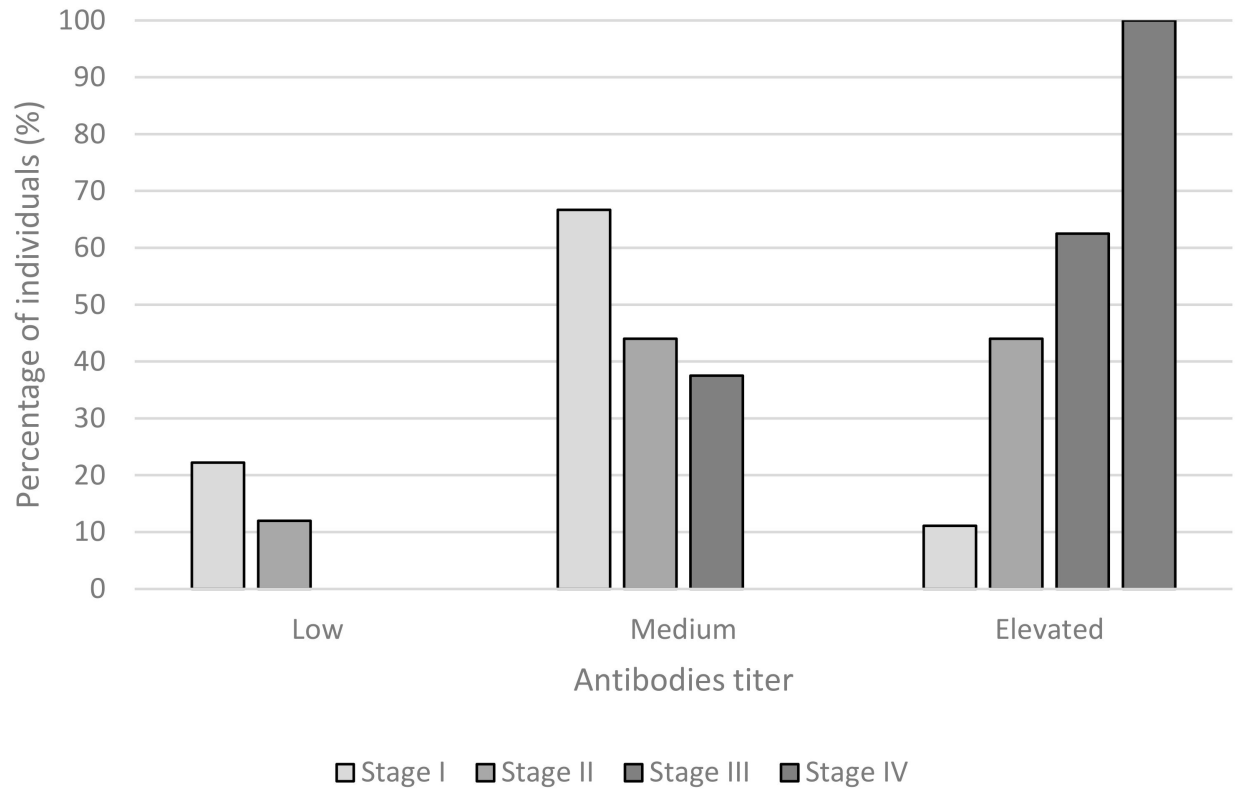

Figure 1. Relationship between clinical stage (stage I: mild disease, stage II: moderate disease, stage III: severe disease, and stage IV: very severe disease) and the presence of antibodies (low: <1:100; medium: between 1:100 and 1:400, and elevated: $>1: 400$ ).

\section{Discussion}

In this work, we observed a seroprevalence of L. infantum infection of $4.74 \%$. This result agrees with data observed in other reported studies on Mediterranean areas, where the prevalence was estimated between $5 \%$ and $57.1 \%$ [16]. In the Balearic Islands, the prevalence was approximately $1 \%$ of 813 dogs in 1999 [47] and $40 \%$ of 40 dogs ranging from 2011 to 2016 [21]. These relevant differences may be due to the sample size used and asymptomatic animals. Our study and others, which demonstrated high prevalence, only analyzed animals with symptoms, suggesting that the actual prevalence may be higher. Our work is the first to analyze and document more than $3000 \mathrm{dogs}$ from the island of 
Ibiza. In other Spanish regions such as Northern Spain, the prevalence rate is lower than in Mediterranean regions at approximately $4 \%$ [17,45], resembling our data. These differences are likely due to environmental conditions and the vector distribution. Gálvez et al., (2020) analyzed the seroprevalence of L. infantum in dogs and sand fly distribution in Spain. They confirmed that the Balearic Islands are hyperendemic with P. perniciosus as the most abundant sand fly vector [21]. On the one hand, the climate and vegetation of Northern Spain are typically oceanic (warm summers and cool winters) and distribute rain throughout the year. On the other hand, the Mediterranean climate is characterized by mild and rainy winters, and dry and hot summers, with variable autumn and spring seasons (both in temperature and rain). This situation promotes the dispersion of L. infantum transmitted vectors [48]. Although the sample sizes were different between the breeds, the robustness of our statistical analysis indicates that differences exist. However, other authors conducted similar studies with similar sample sizes, and the results obtained are comparable to those of our study $[20,49,50]$. Regarding canine breeds, the high seroprevalence found in Boxers and Doberman Pinschers, $39.13 \%$ and $42.86 \%$, respectively, agree with other study results $[2,41,49,51]$, where authors attributed the genetic susceptibility and high prevalence of the Boxer breed to the TAG-8-141 haplotype. Abranches et al., (1991) conducted a study in Portugal showing high prevalence in the Doberman Pinscher and German Shepherd breeds [51]. However, the latter breed had a moderate seroprevalence in our study. Other authors suggested that the elevated susceptibility of the Boxer and Doberman Pinscher is due to three single nucleotide polymorphisms (SNPs) in the Slc11a1 gene, specifically in the promoter regions T151C, A180G, and G318A, associated with these breeds and others, such as the Cocker Spaniel $[40,43]$. In our study, Cocker Spaniels had a high prevalence of infection $(26.83 \%)$. The authors of $[40,43]$ explained that these three SNPs of the Slc11a1 gene are associated with a visceral presentation of the disease, which was similar in the different breeds analyzed. Although there are fewer studies on the presence of these haplotypes and SNPs in all dogs, the breeds with the lowest prevalence (Bichon, French Bulldog, Pug, and Chihuahua) and the highest prevalence (Doberman Pinscher, Boxer, Great Dane, Dogue de Bordeaux, and Boxer) appear to have common ancestors. A cladogram showed that their bootstrap supported more than $70 \%$ with over 150,000 SNPs [52,53]. Only the French Bulldog, genetically similar to the Boxer and Dogue de Bordeaux, presents a low seroprevalence of L. infantum infection in our study. Currently, there are no published scientific data to explain (in a genetic manner) the low prevalence of infection by L. infantum in this breed.

To describe the infected population, although the cutaneous presentation is the most common in the dogs studied in this work regardless of breed and other factors, other authors found no relationship between sex and prevalence of L. infantum infection in Spain and Portugal [45,51]. Our results show similar seroprevalence in males and females, whereas some authors found a higher prevalence in males than females [54-57]. Viol et al., (2012) claimed these differences result from breeding males' preference for surveillance or hunting activities, which exposes them to insect bites and infection by L. infantum [55]. Our data likely show similar seroprevalence because the dogs included in our study were not engaged in surveillance or hunting activities. The same authors [55] also found lower prevalence in adult dogs than younger and older dogs ( $>7$ years), whereas Dantas-Torres et al., (2006) demonstrated a correlation between early age and prevalence [55,57]. Some studies indicated that the L. infantum infection presented two peaks in younger dogs (1-2 years) and a second peak at 7-8 years [58]. However, our results show no statistical difference between ages. According to studies performed in Brazil and Tunisia, the highest prevalence was found in dogs with clinical stage II, i.e., moderate disease [59,60].

We observed that antibody titers are associated with disease presentation; however, some authors ascribed the clinical picture to other factors such as eosinophil and alphaglobulin values [61]. We showed that animals with low antibody titers contracted the cutaneous form. These results are concordant with those obtained in a recent metaanalysis indicating that the cutaneous form could lead to more advanced stages of vis- 
ceral disease [54]. The antibodies' titer is related to clinical stage according to MartinezOrellana et al., (2017) [49]. The authors argued that the clinical stage depends on the host's immunologic response; therefore, the Th2 response produces ineffective antibodies and increases disease. Solano-Gallego et al., (2011) associated the clinical stage with antibody titers. Therefore, the clinical stage system is based on clinical signs, clinicalpathological abnormalities, and serologic status, directly associated with antibody titers of L. infantum [2].

\section{Conclusions}

Our study concludes that the total seroprevalence of L. infantum infection is $4.74 \%$ on a Mediterranean island, Ibiza Island. Our results confirm that the seroprevalence of L. infantum is linked to the canine breed but not with antibody titers. The differences in prevalence and breeds may be explained by three polymorphisms present in the Slc11a1 gene. More studies should endeavor to document these interactions. Regarding the profile of seropositive animals, the distribution was similar to other studies. However, a relationship was observed between the number of antibody titers and the presentation of the disease. These data may indicate that the cutaneous presentation is anterior to the visceral one; however, future trials are needed.

Author Contributions: Conceptualization, L.L.; methodology, L.L.; formal analysis, M.E. and L.L.; investigation, M.E., P.J.M.-G., and L.L.; data curation, M.E.; writing-original draft preparation, M.E.; writing-review and editing, L.L. and P.J.M.-G.; supervision, P.J.M.-G. and L.L. All authors have read and agreed to the published version of the manuscript.

Funding: This work was funded by the grants for emerging research groups of Generalitat Valenciana (GV/2021/104). The funding agency was not involved in the design of study, data collection, analysis of data or manuscript writing.

Institutional Review Board Statement: The study was conducted according to the guidelines of the Declaration of Helsinki and approved by the Animal Experimentation Ethics Committee of the Universidad Cardenal Herrera CEU (2020/VSC/PEA/0216).

Informed Consent Statement: Informed consent was obtained from all subjects involved in the study. Data Availability Statement: Not applicable.

Acknowledgments: We are grateful to the Veterinary Medicine Faculty of Universidad Cardenal Herrera-CEU, Vidal Pereyra Veterinarian Clinic, Vila Veterinaris, and Raquel Prats.

Conflicts of Interest: The authors declare no conflict of interest.

\section{References}

1. Mohebali, M.; Malmasi, A.; Khodabakhsh, M.; Zarei, Z.; Akhoundi, B.; Hajjaran, H.; Azarm, A. Feline leishmaniosis due to Leishmania infantum in Northwest Iran: The role of cats in endemic areas of visceral leishmaniosis. Vet. Parasitol. Reg. Stud. Rep. 2017, 9, 13-16. [CrossRef]

2. Solano-Gallego, L.; Miró, G.; Koutinas, A.; Cardoso, L.; Pennisi, M.G.; Ferrer, L.; Bourdeau, P.; Oliva, G.; Baneth, G. LeishVet Guidelines for the practical management of canine leishmaniosis. Parasites Vectors 2011, 4, 86. [CrossRef]

3. Solano-Gallego, L.; Morell, P.; Arboix, M.; Alberola, J.; Ferrer, L. Prevalence of leishmania infantum infection in dogs living in an area of canine leishmaniasis endemicity using PCR on several tissues and serology. J. Clin. Microbiol. 2001, 39, 560-563. [CrossRef]

4. Leontides, L.S.; Saridomichelakis, M.N.; Billinis, C.; Kontos, V.; Koutinas, A.F.; Galatos, A.D.; Mylonakis, M.E. A Cross-sectional study of Leishmania Spp. infection in clinically healthy dogs with polymerase chain reaction and serology in Greece. Vet. Parasitol. 2002, 109, 19-27. [CrossRef]

5. Berrahal, F.; Mary, C.; Roze, M.; Berenger, A.; Escoffier, K.; Lamouroux, D.; Dunan, S. Canine leishmaniasis: Identification of asymptomatic carriers by polymerase chain reaction and immunoblotting. Am. J. Trop. Med. Hyg. 1996, 55, 273-277. [CrossRef]

6. Akhoundi, M.; Kuhls, K.; Cannet, A.; Votýpka, J.; Marty, P.; Delaunay, P.; Sereno, D. A Historical overview of the classification, evolution, and dispersion of leishmania parasites and sandflies. PLoS Negl. Trop. Dis. 2016, 10, e0004349. [CrossRef] [PubMed]

7. Mhadhbi, M.; Sassi, A. Infection of the Equine population by leishmania parasites. Equine Vet. J. 2020, 52, 28-33. [CrossRef] [PubMed]

8. Asfaram, S.; Fakhar, M.; Teshnizi, S.H. Is the cat an important reservoir host for visceral leishmaniasis? A systematic review with meta-analysis. J. Venom. Anim. Toxins Incl. Trop. Dis. 2019, 25, e20190012. [CrossRef] 
9. González, E.; Molina, R.; Iriso, A.; Ruiz, S.; Aldea, I.; Tello, A.; Fernández, D.; Jiménez, M. Opportunistic feeding behaviour and leishmania infantum detection in phlebotomus perniciosus females collected in the human leishmaniasis focus of Madrid, Spain (2012-2018). PLoS Negl. Trop. Dis. 2021, 15, e0009240. [CrossRef] [PubMed]

10. Moraes-Silva, E.; Antunes, F.R.; Rodrigues, M.S.; da Silva Julião, F.; Dias-Lima, A.G.; Lemos-de-Sousa, V.; de Alcantara, A.C.; Reis, E.A.G.; Nakatani, M.; Badaró, R.; et al. Domestic swine in a visceral leishmaniasis endemic area produce antibodies against multiple leishmania infantum antigens but apparently resist to L. infantum infection. Acta Trop. 2006, 98, 176-182. [CrossRef]

11. Navea-Pérez, H.M.; Díaz-Sáez, V.; Corpas-López, V.; Merino-Espinosa, G.; Morillas-Márquez, F.; Martín-Sánchez, J. Leishmania infantum in wild rodents: Reservoirs or just irrelevant incidental hosts? Parasitol. Res. 2015, 114, 2363-2370. [CrossRef]

12. Tsokana, C.N.; Sokos, C.; Giannakopoulos, A.; Birtsas, P.; Athanasiou, L.V.; Valiakos, G.; Sofia, M.; Chatzopoulos, D.C.; Kantere, M.; Spyrou, V.; et al. Serological and molecular investigation of selected parasitic pathogens in European brown hare (Lepus Europaeus) in Greece: Inferring the ecological niche of toxoplasma gondii and leishmania infantum in hares. Parasitol. Res. 2019, 118, 2715-2721. [CrossRef] [PubMed]

13. Abbate, J.M.; Arfuso, F.; Napoli, E.; Gaglio, G.; Giannetto, S.; Latrofa, M.S.; Otranto, D.; Brianti, E. Leishmania infantum in wild animals in endemic areas of southern Italy. Comp. Immunol. Microbiol. Infect. Dis. 2019, 67, 101374. [CrossRef]

14. El Hamouchi, A.; El Kacem, S.; Ejghal, R.; Lemrani, M. Genetic polymorphism in leishmania infantum isolates from human and animals determined by nagt PCR-RFLP. Infect. Dis. Poverty 2018, 7, 54. [CrossRef]

15. Solano-Gallego, L.; Koutinas, A.; Miró, G.; Cardoso, L.; Pennisi, M.G.; Ferrer, L.; Bourdeau, P.; Oliva, G.; Baneth, G. Directions for the diagnosis, clinical staging, treatment and prevention of canine leishmaniosis. Vet. Parasitol. 2009, 165, 1-18. [CrossRef]

16. Morillas, F.; Sanchez Rabasco, F.; Ocaña, J.; Martin-Sanchez, J.; Ocaña-Wihelmi, J.; Acedo, C.; Sanchiz-Marin, M.C. Leishmaniosis in the focus of the Axarquía region, Malaga province, southern Spain: A survey of the human, dog, and vector. Parasitol. Res. 1996, 82, 569-570. [CrossRef] [PubMed]

17. Amusategui, I.; Sainz, A.; Aguirre, E.; Tesouro, M.A. Seroprevalence of leishmania infantum in northwestern Spain, an area traditionally considered free of leishmaniasis. Ann. N. Y. Acad. Sci. 2004, 1026, 154-157. [CrossRef] [PubMed]

18. Otranto, D.; Napoli, E.; Latrofa, M.S.; Annoscia, G.; Tarallo, V.D.; Greco, G.; Lorusso, E.; Gulotta, L.; Falsone, L.; Basano, F.S.; et al. Feline and canine leishmaniosis and other vector-borne diseases in the Aeolian islands: Pathogen and vector circulation in a confined environment. Vet. Parasitol. 2017, 236, 144-151. [CrossRef]

19. Tamponi, C.; Scarpa, F.; Carta, S.; Knoll, S.; Sanna, D.; Gai, C.; Pipia, A.P.; Dessì, G.; Casu, M.; Varcasia, A.; et al. Seroprevalence and risk factors associated with leishmania infantum in dogs in Sardinia (Italy), an endemic island for leishmaniasis. Parasitol. Res. 2021, 120, 289-300. [CrossRef] [PubMed]

20. Burnham, A.C.; Ordeix, L.; Alcover, M.M.; Martínez-Orellana, P.; Montserrat-Sangrà, S.; Willen, L.; Spitzova, T.; Volf, P.; SolanoGallego, L. Exploring the relationship between susceptibility to canine leishmaniosis and anti-phlebotomus perniciosus saliva antibodies in Ibizan hounds and dogs of other breeds in Mallorca, Spain. Parasites Vectors 2020, 13, 129. [CrossRef]

21. Gálvez, R.; Montoya, A.; Cruz, I.; Fernández, C.; Martín, O.; Checa, R.; Chicharro, C.; Migueláñez, S.; Marino, V.; Miró, G. Latest trends in leishmania infantum infection in dogs in Spain, part I: Mapped seroprevalence and sand fly distributions. Parasites Vectors 2020, 13, 204. [CrossRef]

22. De Araujo, F.J.; da Silva, L.D.O.; Mesquita, T.G.; Pinheiro, S.K.; Wonei de Seixas, V.; Chrusciak-Talhari, A.; de Oliveira Guerra, J.A.; Talhari, S.; Ramasawmy, R. Polymorphisms in the TOLLIP gene influence susceptibility to cutaneous leishmaniasis caused by leishmania guyanensis in the Amazonas State of Brazil. PLoS Negl. Trop. Dis. 2015, 9, e0003875. [CrossRef]

23. De Vasconcelos, T.C.B.; Doyen, N.; Cavaillon, J.-M.; Bruno, S.F.; de Campos, M.P.; de Miranda, L.H.M.; de Fátima Madeira, M.; Belo, V.S.; Figueiredo, F.B. Cytokine and INOS profiles in lymph nodes of dogs naturally infected with leishmania infantum and their association with the parasitic DNA load and clinical and histopathological features. Vet. Parasitol. 2016, $227,8-14$. [CrossRef] [PubMed]

24. Hernández-Rivera, M.P.; Ramírez-Ramírez, A.; Chiñas-Pérez, A.; Monroy-Ostria, A.; Cancino-Díaz, M.E.; Hernández-Montes, O. NRAMP1 Polymorphisms like susceptibility marker in Mexican focus of cutaneous leishmaniasis. Biomed. Res. Int. 2016, 2016, 7951285. [CrossRef] [PubMed]

25. Kumar, D.; Tiwary, P.; Chakravarty, J.; Sundar, S. Association of Interleukin-18 gene polymorphism with susceptibility to visceral leishmaniasis in endemic area of Bihar, an Indian population. Sci. World J. 2014, 2014, 852104. [CrossRef]

26. Ortiz-Flores, A.; De la Rosa-López, G.; Zavaleta-Villa, B.; Chávez-López, S.; Pastor-Santiago, J.; Guzmán-Bracho, C.; RomeroValdovinos, M.; Martínez-Hernández, F.; Olivo-Díaz, A. Association of leishmaniasis with TNF alpha promoter and SLC11A1 gene polymorphisms in patients of two endemic areas in Mexico. Microbes Infect. 2015, 17, 387-394. [CrossRef]

27. Ready, P.D. Epidemiology of visceral leishmaniasis. Clin. Epidemiol. 2014, 6, 147-154. [CrossRef] [PubMed]

28. Sophie, M.; Hameed, A.; Muneer, A.; Samdani, A.J.; Saleem, S.; Azhar, A. SLC11A1 Polymorphisms and host susceptibility to cutaneous leishmaniasis in Pakistan. Parasites Vectors 2017, 10, 12. [CrossRef] [PubMed]

29. Soutter, F.; Solano-Gallego, L.; Attipa, C.; Gradoni, L.; Fiorentino, E.; Foglia Manzillo, V.; Oliva, G.; Tasker, S.; Helps, C.; Catchpole, B. An investigation of polymorphisms in innate and adaptive immune response genes in canine leishmaniosis. Vet. Parasitol. 2019, 269, 34-41. [CrossRef] [PubMed]

30. Solano-Gallego, L.; Llull, J.; Ramos, G.; Riera, C.; Arboix, M.; Alberola, J.; Ferrer, L. The Ibizian hound presents a predominantly cellular immune response against natural leishmania infection. Vet. Parasitol. 2000, 90, 37-45. [CrossRef] 
31. De Vasconcelos, T.C.B.; Furtado, M.C.; Belo, V.S.; Morgado, F.N.; Figueiredo, F.B. Canine susceptibility to visceral leishmaniasis: A systematic review upon genetic aspects, considering breed factors and immunological concepts. Infect. Genet. Evol. 2019, 74, 103293. [CrossRef]

32. Barbiéri, C.L. Immunology of canine leishmaniasis. Parasite Immunol. 2006, 28, 329-337. [CrossRef]

33. Gradoni, L. Canine leishmania vaccines: Still a long way to go. Vet. Parasitol. 2015, 208, 94-100. [CrossRef]

34. Balaña-Fouce, R.; Calvo-Álvarez, E.; Álvarez-Velilla, R.; Prada, C.F.; Pérez-Pertejo, Y.; Reguera, R.M. Role of Trypanosomatid's arginase in polyamine biosynthesis and pathogenesis. Mol. Biochem. Parasitol. 2012, 181, 85-93. [CrossRef] [PubMed]

35. Guerra, J.M.; Fernandes, N.C.C.A.; Réssio, R.A.; Kimura, L.M.; Barbosa, J.E.R.; Taniguchi, H.H.; Hiramoto, R.M.; Motoie, G.; Tolezano, J.E.; Cogliati, B. Cytokine profile and parasite load in lymph nodes of dogs naturally infected with leishmania infantum from distinct epidemiological scenarios in São Paulo State, Brazil. Vet. Immunol. Immunopathol. 2021, 233, 110198. [CrossRef]

36. Verçosa, B.L.A.; Muniz-Junqueira, M.I.; Menezes-Souza, D.; Fujiwara, R.T.; Melo, M.N.; Vasconcelos, A.C. The balance between IL-12/IL4 in renal tissue switches the inflammatory response arm and shows relationship with the clinical signs in leishmaniainfected dogs. Vet. Immunol. Immunopathol. 2021, 234, 110196. [CrossRef] [PubMed]

37. Batista, L.F.S.; Utsunomiya, Y.T.; Silva, T.B.F.; Dias, R.A.; Tomokane, T.Y.; Pacheco, A.D.; da Matta, V.L.R.; Silveira, F.T.; Marcondes, M.; Nunes, C.M.; et al. Genome-wide association study of cell-mediated response in dogs naturally infected by leishmania infantum. Infect. Immun. 2016, 84, 3629-3637. [CrossRef]

38. De Oliveira Cardoso, J.M.; de Brito, R.C.F.; Costa, A.F.P.; Siqueira Mathias, F.A.; Soares Reis, L.E.; Vieira, J.F.P.; de Oliveira Aguiar Soares, R.D.; Reis, A.B.; Roatt, B.M. IL-10 receptor blockade controls the In Vitro infectivity of leishmania infantum and promotes a Th1 activation in PBMC of dogs with visceral leishmaniasis. Mol. Immunol. 2021, 137, 20-27. [CrossRef] [PubMed]

39. Santos, C.d.O.; Costa, S.F.; Souza, F.S.; Mendes, J.M.F.; de Pinheiro, C.G.M.; Moreira, D.R.d.M.; Silva, L.K.; de Lima, V.M.F.; de Sá Oliveira, G.G. Blocking IL-10 signaling with soluble IL-10 receptor restores In Vitro specific lymphoproliferative response in dogs with leishmaniasis caused by leishmania infantum. PLoS ONE 2021, 16, e0239171. [CrossRef]

40. Utsunomiya, Y.T.; Ribeiro, É.S.; Quintal, A.P.N.; Sangalli, J.R.; Gazola, V.R.; Paula, H.B.; Trinconi, C.M.; Lima, V.M.F.; Perri, S.H.V.; Taylor, J.F.; et al. Genome-wide scan for visceral leishmaniasis in mixed-breed dogs identifies candidate genes involved in $\mathrm{T}$ helper cells and macrophage signaling. PLoS ONE 2015, 10, e0136749. [CrossRef]

41. Quilez, J.; Martínez, V.; Woolliams, J.A.; Sanchez, A.; Pong-Wong, R.; Kennedy, L.J.; Quinnell, R.J.; Ollier, W.E.R.; Roura, X.; Ferrer, L.; et al. Genetic control of canine leishmaniasis: Genome-wide association study and genomic selection analysis. PLoS ONE 2012, 7, e35349. [CrossRef]

42. Batista, L.F.S.; Torrecilha, R.B.P.; Silva, R.B.; Utsunomiya, Y.T.; Silva, T.B.F.; Tomokane, T.Y.; Pacheco, A.D.; Bosco, A.M.; Paulan, S.C.; Rossi, C.N.; et al. Chromosomal segments may explain the antibody response cooperation for canine leishmaniasis pathogenesis. Vet. Parasitol. 2020, 288, 109276. [CrossRef] [PubMed]

43. Sanchez-Robert, E.; Altet, L.; Utzet-Sadurni, M.; Giger, U.; Sanchez, A.; Francino, O. Slc11a1 (formerly Nramp1) and susceptibility to canine visceral leishmaniasis. Vet. Res. 2008, 39, 36. [CrossRef] [PubMed]

44. Searle, S.; Blackwell, J.M. Evidence for a functional repeat polymorphism in the promoter of the human NRAMP1 gene that correlates with autoimmune versus infectious disease susceptibility. J. Med. Genet. 1999, 36, 295-299. [PubMed]

45. Miró, G.; Checa, R.; Montoya, A.; Hernández, L.; Dado, D.; Gálvez, R. Current situation of leishmania infantum infection in shelter dogs in northern Spain. Parasites Vectors 2012, 5, 60. [CrossRef]

46. Olías-Molero, A.I.; Corral, M.J.; Jiménez-Antón, M.D.; Alunda, J.M. Early antibody response and clinical outcome in experimental canine leishmaniasis. Sci. Rep. 2019, 9, 18606. [CrossRef]

47. Puntas, M.G.S. Estudio Epidemiologico de la Leishmaniosis en la Isla de Menorca. Ph.D. Thesis, Universitat de Barcelona, Barcelona, Spain, 1991.

48. Chalghaf, B.; Chemkhi, J.; Mayala, B.; Harrabi, M.; Benie, G.B.; Michael, E.; Ben Salah, A. Ecological niche modeling predicting the potential distribution of leishmania vectors in the Mediterranean basin: Impact of climate change. Parasites Vectors 2018, 11, 461. [CrossRef]

49. Martínez-Orellana, P.; Marí-Martorell, D.; Montserrat-Sangrà, S.; Ordeix, L.; Baneth, G.; Solano-Gallego, L. Leishmania infantumspecific IFN- $\gamma$ production in stimulated blood from dogs with clinical leishmaniosis at diagnosis and during treatment. Vet. Parasitol. 2017, 248, 39-47. [CrossRef]

50. Sanchez-Robert, E.; Altet, L.; Sanchez, A.; Francino, O. Polymorphism of Slc11a1 (Nramp1) gene and canine leishmaniasis in a case-control study. J. Hered. 2005, 96, 755-758. [CrossRef]

51. Abranches, P.; Silva-Pereira, M.C.; Conceição-Silva, F.M.; Santos-Gomes, G.M.; Janz, J.G. Canine leishmaniasis: Pathological and ecological factors influencing transmission of infection. J. Parasitol. 1991, 77, 557-561. [CrossRef]

52. Parker, H.G.; Dreger, D.L.; Rimbault, M.; Davis, B.W.; Mullen, A.B.; Carpintero-Ramirez, G.; Ostrander, E.A. Genomic analyses reveal the influence of geographic origin, migration, and hybridization on modern dog breed development. Cell Rep. 2017, 19, 697-708. [CrossRef] [PubMed]

53. Vonholdt, B.M.; Pollinger, J.P.; Lohmueller, K.E.; Han, E.; Parker, H.G.; Quignon, P.; Degenhardt, J.D.; Boyko, A.R.; Earl, D.A.; Auton, A.; et al. Genome-wide SNP and haplotype analyses reveal a rich history underlying dog domestication. Nature 2010, 464, 898-902. [CrossRef]

54. Oliveira, C.S.; Ratzlaff, F.R.; Pötter, L.; Romão, P.R.T.; de Avila Botton, S.; Vogel, F.S.F.; Sangioni, L.A. Clinical and pathological aspects of canine cutaneous leishmaniasis: A meta-analysis. Acta Parasitol. 2019, 64, 916-922. [CrossRef] [PubMed] 
55. Viol, M.A.; Lima, V.M.F.; Aquino, M.C.C.; Gallo, G.; Alves, I.P.; Generoso, D.; Perri, S.H.V.; Lucheis, S.B.; Langoni, H.; Nunes, C.M.; et al. Detection of cross infections by Leishmania Spp. and Trypanosoma Spp. in dogs using indirect immunoenzyme assay, indirect fluorescent antibody test and polymerase chain reaction. Parasitol. Res. 2012, 111, 1607-1613. [CrossRef]

56. Zaffaroni, E.; Rubaudo, L.; Lanfranchi, P.; Mignone, W. Epidemiological patterns of canine leishmaniasis in Western Liguria (Italy). Vet. Parasitol. 1999, 81, 11-19. [CrossRef]

57. Dantas-Torres, F.; de Brito, M.E.F.; Brandão-Filho, S.P. Seroepidemiological survey on canine leishmaniasis among dogs from an urban area of Brazil. Vet. Parasitol. 2006, 140, 54-60. [CrossRef]

58. Gálvez, R.; Miró, G.; Descalzo, M.A.; Nieto, J.; Dado, D.; Martín, O.; Cubero, E.; Molina, R. Emerging trends in the seroprevalence of canine leishmaniasis in the Madrid region (Central Spain). Vet. Parasitol. 2010, 169, 327-334. [CrossRef] [PubMed]

59. Mhadhbi, M.; Chaabouni, A.; Bouabid, C.; Sassi, A. Relationships between specific antibody responses and clinical signs of dogs living in Tunisian endemic areas of canine leishmaniasis caused by leishmania infantum. Acta Trop. 2021, 218, 105906. [CrossRef]

60. Fernandes, M.A.; Leonel, J.A.F.; Isaac, J.A.; Benassi, J.C.; Silva, D.T.; Spada, J.C.P.; Pereira, N.W.B.; Ferreira, H.L.; Keid, L.B.; Soares, R.M.; et al. Molecular detection of leishmania infantum DNA according to clinical stages of leishmaniasis in dog. Rev. Bras. Parasitol. Vet. 2019, 28, 194-202. [CrossRef] [PubMed]

61. Amusategui, I.; Sainz, A.; Rodríguez, F.; Tesouro, M.A. Distribution and relationships between clinical and biopathological parameters in canine leishmaniasis. Eur. J. Epidemiol. 2003, 18, 147-156. [CrossRef] 